\section{Federation University ResearchOnline}

\section{https://researchonline.federation.edu.au}

Copyright Notice

This is the author's version of a work that was accepted for publication in Current Aging Science, 2016. Changes resulting from the publishing process, such as peer review, editing, corrections, structural formatting, and other quality control mechanisms may not be reflected in this document.

Available online: $\underline{\text { https://doi.org/10.2174/1874609809666160506122322 }}$

Copyright @ 2016 Bentham Science Publishers 


\title{
Ageing and Learning in Australia: Arguing an Evidence Base for Informed and Equitable Policy
}

\author{
Michael Cuthill*a ${ }^{\text {a }}$, Laurie Buys ${ }^{* b}$, Bruce Wilson ${ }^{1}$, Helen Kimberley ${ }^{2}$, Denise Reghenzani ${ }^{3}$, Peter \\ Kearns ${ }^{4}$, Sally Thompson ${ }^{5,}$ Barry Golding ${ }^{6,}$ Jo Root $^{7}$ and Rhonda Weston ${ }^{8}$
}

anstitute for Resilient Regions, University of Southern Queensland, Toowoomba, Queensland,
Australia, ${ }^{b}$ School of Design, Creative Industries Faculty, Queensland University of Technology,
Brisbane, Queensland, Australia, ${ }^{1}$ RMIT University, ${ }^{2}$ Brotherhood of St Laurence, ${ }^{3}$ PASCAL,
${ }^{4}$ PASCAL, ${ }^{5}$ Adult Learning Australia, ${ }^{6}$ Federation University,' ${ }^{7}$ Council of the Ageing, Australia,
${ }^{8}$ University of the Third Age

\begin{abstract}
Given Australia's population ageing and predicted impacts related to health, productivity, equity and enhancing quality of life outcomes for senior Australians, lifelong learning has been identified as a pathway for addressing the risks associated with an ageing population. To date Australian governments have paid little attention to addressing these needs and thus, there is an urgent need for policy development for lifelong learning as a national priority. The purpose of this article is to explore the current lifelong learning context in Australia and to propose a set of factors that are most likely to impact learning in later years.
\end{abstract}

Keywords: Ageing, learning, Australia, older adults, policy.

\section{INTRODUCTION}

\section{THE CONTEXT FOR AGEING AND LEARNING IN AUSTRALIA}

Adult Learning Australia [1] argues the accumulative skills and knowledge developed over a lifetime that older people have is extremely beneficial:

... a population skewed towards more skilled and knowledgeable workers and community members should have enormous pay-offs in productivity and in its ability to manage ongoing societal challenges. (p4)

Harnessing this potential through provision of appropriate learning opportunities for seniors offers clear health, social and economic benefits, and provides a pathway for addressing the risks associated with an ageing population [2-6]. The concept of lifelong learning provides a framework for exploring this opportunity. Thus the purpose of this article is to explore the current lifelong learning context in Australia and to propose a set of factors that are most likely to impact learning in later years.

Lifelong learning, including learning in later years, addresses four key elements, which includes: a) the entire lifespan, from 'cradle to grave'; b) aims to improve understanding, knowledge and skills; c) formal and informal learning - through education, as a citizen, at work and at leisure; and d) a broad scope for the purpose of learning which incorporates economic, social and other individual outcomes $[3,7-9]$.

\footnotetext{
*Address correspondence to this author at the Deputy Vice-Chancellor's Office (Research and Innovation), University of Southern Queensland, Brisbane, Australia; Tel: + 61 746312479; Ext: 2479;

E-mail: Michael.Cuthill@usq.edu.au
}

Tikkanen and Nyhan [10] argue that, in responding to support for seniors' learning, “... society, work organisations and individuals must think of ageing as a lifelong learning and developmental process in which one continuously takes on new challenges in line with one's interests, opportunities and limitations" (p3). However, while governments direct ongoing and explicit attention to supporting learning opportunities for younger and middle age groups, there remains a general and ongoing lack of understanding of, and investment to support appropriate learning opportunities for older Australians [11-14].

Clearly, the stereotypical perception of ageing as a process of 'decline' [15] or 'disengagement' [16] is no longer valid. Advances in health, communications, education, and technology mean Australians can now live longer, healthier and more productive lives [2]. As the Australian Government [2] has argued, "The challenge is to re-shape workplaces, communities and society to facilitate the contribution of senior Australians rather than to reinforce outdated approaches that create barriers to their participation and lead to disengagement and social isolation" ( $\mathrm{p} 1)$. In responding to this challenge, over recent years, there has been an emerging policy and sectoral dialogue related to ageing and learning in Australia [e.g. 2, 5, 9, 14, 16]. However, there remains an ongoing absence of any overriding national policy to support and direct learning for all Australians across their life course [8, 17-19].

The current situation sits at odds with the view of the Australian Productivity Commission [5] who argue that, "The preferable time to contemplate the policy implications of these developments is while these near-inescapable trends ... [associated with an ageing population] ... are still in their infancy" (p19). The contemporary context of an ageing 
population, especially in regards to health, productivity, equity and enhancing quality of life outcomes for senior Australians, underpins the need for policy development as a priority area of focus [20].

However, in Australia, at government policy and operational levels, there has been an ongoing lack of attention to broad concepts of lifelong learning [17]. Lifelong learning is described as the continuous development of skills and knowledge, which “...not only enhances social inclusion, active citizenship and personal development, but also competitiveness and employability" (p399) [21]. These learning opportunities can be separated into three reasonably discreet (but sometimes overlapping) settings - formal, work and community based [8, 22-23], thus highlighting the need for a broad approach to seniors' learning rather than an emphasis solely on formal education.

While various ageing initiatives have discussed 'what' factors might underpin healthy, active or productive ageing [e.g. 5, 7, 25-26], little direction has been provided in 'how' to operationalise the goals that have been identified [20]. The concept of lifelong learning presents clear opportunities in terms of addressing the challenges associated with the ageing population $[5,14]$. However, there is a clear need to identify and integrate the perspectives of Australian seniors as key stakeholders within this policy discourse.

While the Australia Government [2] acknowledges lifelong learning for seniors as a difficult policy challenge, as Kearns [17] states, there is none-the-less a need for "... more comprehensive and coherent policies to support learning throughout life in many contexts ... [and this] ... should be seen as a necessary strategic investment in Australia's future ..." (viii). From both economic and equity perspectives, seniors need to be included in helping build the future Australia. It has been argued that the current top down approach to the ageing population has resulted in a "... disjuncture in the eyes of stakeholders between what older Australians want and the implementation of policy and practice" (p772) [27].

\section{CONCEPTUALISING AGEING AND LEARNING IN AUSTRALIA}

The United Nations (UN) argues that 'participation' is a basic right for older people, and calls for the "Empowerment of older persons to fully and effectively participate in the economic, political and social lives of their societies, including through income generation and voluntary work" [24] (2:Part 1 section 12c). Internationally, interrelated ageing frameworks, such as age friendly communities and active ageing have echoed the UN call for development of policies and services in response to the needs and aspirations of older people. For example, the World Health Organisation [26] describe the notion of 'active ageing' as, “... the process of optimising opportunities for health, participation and security in order to enhance the quality of life as people age" (p12). Echoing this line, an 'age friendly community' is one that supports active social and economic participation in the community, and provision of appropriate services and infrastructure for seniors [28].

A focus on seniors' engagement in social and economic life forms a key focus within such frameworks [9, 29]. This is an important focus as seniors are identified as a population group increasingly at risk of social and economic exclusion [30]. One opportunity for operationalising seniors' engagement which is receiving increasing attention, is the provision of appropriate learning opportunities. In our conceptual framework, we argue that seniors' engagement, processed through appropriate learning opportunities, can help drive active ageing (Fig. 1).

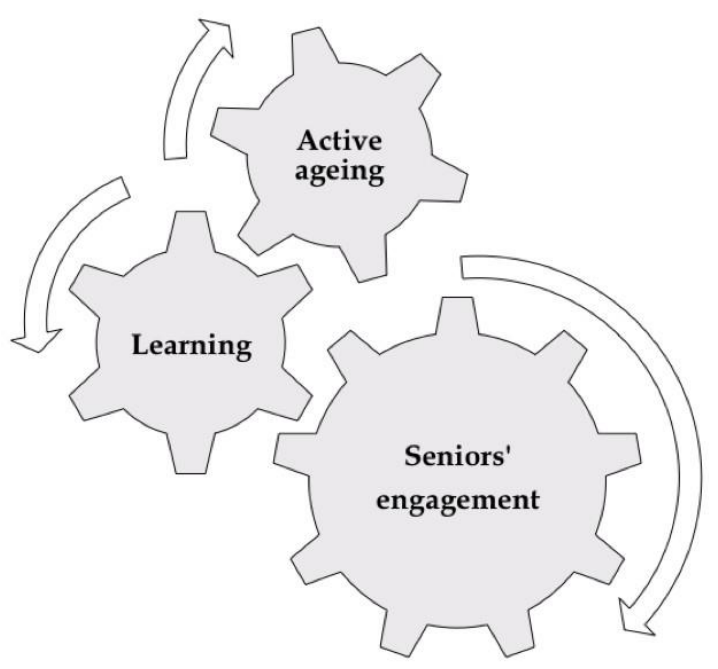

Fig. (1). Lifelong learning and active ageing.

Seniors' engagement, through lifelong learning, contrasts with the more traditional view of a three stage life course where learning is primarily the domain of younger people, work is the domain of middle age and retirement is the domain of seniors. The concept of learning across the ages and the opportunities it offers has resulted in widespread endorsement internationally of the value of learning for seniors $[1,7,25,26,31]$. However, currently, we have a limited understanding of what 'appropriate seniors' learning opportunities' might be [20] and a number of questions must first be addressed to inform policy development in this area.

For example,

1. What knowledge and skills does an older Australian need to survive and thrive in the $21^{\text {st }}$ Century?

2. Where and how are these knowledge and skills acquired, particularly if you come from a background of socioeconomic disadvantage?

3. Why, despite the imperative to stay current and wellinformed, do Australian seniors continue to have very participation rates in learning?

As Thompson et. el. [16] suggest, "Older Australians want to learn, but they don't necessarily want to learn in the same way as younger Australians" (p14). However, it is concerning that so little is known about seniors' learning experiences and the factors underpinning their involvement in later-life learning [20, 32]. Development of appropriate policy and operational responses requires better understanding of these factors [27]. Working from the three questions listed above, the following sections of this paper begin a dialogue as a basis for an ageing and learning research framework. 


\section{THE IMPORTANCE OF PROVIDING APPROPRIATE OPPORTUNITIES FOR SENIORS' LEARNING}

A fundamental premise, widely documented in an extensive and diverse set of government, sectoral and research literature, is that investment in appropriate learning opportunities for seniors facilitates health, social and economic outcomes [3, 7, 8, 21, 26, 33-38] (Fig. 2).

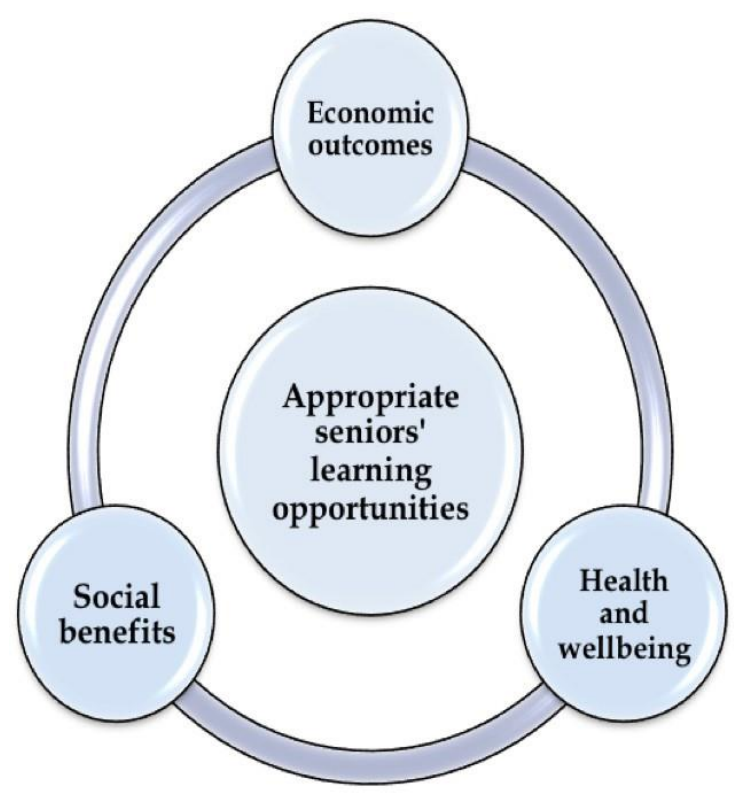

Fig. (2). Appropriate seniors' learning opportunities as the driver for health, social and economic outcomes.

The promise of such outcomes has resulted in widespread attention to lifelong learning across the world [34]. Overall, as Schuller and Watson [3] argue in their comprehensive and wide ranging $U K$ Independent Inquiry into the Future for Lifelong Learning, “... the case is compelling. We have no doubt that lifelong learning already makes a major contribution to sustaining economic and social wellbeing, to enabling people to understand, adapt to and shape change, and to promoting social justice ..." (p21). Of course, the concept of lifelong learning includes older persons, indicating that the outcomes listed above are equally relevant to seniors' engagement in learning as to all other age cohorts [2, 9, 20, 29, $39-41]$. The following paragraphs provide an initial description of this relevance.

Perhaps garnering the most headline interest in Australia currently, in light of both the present tight economic climate and the anticipated costs of an ageing population, is the opportunity for “... turning grey into gold" (p1) [6]. This report suggests that development and utilisation of seniors' human capital presents enormous economic potential. This potential is highlighted through recent research showing that increasing education attainment and learning opportunities by one percentage point across all age levels in each of the 51 largest metropolitan areas in the USA, generates an additional $\$ 124$ billion in aggregate annual personal income, as well as contributing to better social and well-being outcomes [4].

Consideration of the strong link between seniors' learning and enhanced economic outcomes is essential in terms of a knowledge-based economy, particularly so in light of an ageing population and their ongoing productivity [36]. As Adult Learning Australia [1] argue, the provision of appropriate learning opportunities for seniors has the potential “... to extend working life, to assist in career transitions into more senior friendly job roles and to maintain health and wellbeing" (p10). Presentation of such opportunities should be seen as a good investment in both economic and equity terms.

However, as the Australian Human Rights Commission [42] note, "Currently, older Australians are underrepresented in paid work. Underemployment is often symptomatic of other forms of exclusion including participation in the community. Social exclusion and isolation, in turn, have significant impacts on physical and emotional wellbeing" (p18). Equity considerations appear to be receiving little attention in the dialogue around harnessing seniors' productivity. Older people from low socio-economic backgrounds (and this includes a large percentage of Australian elders), seniors with mobility and health issues, and those with limited capacity for formal learning will likely be further disadvantaged if social equity is not a key consideration within productivity discussions. Attention is required to the provision of appropriate learning opportunities that support equity in seniors' economic engagement, what Jackson [31] describes as "... a critically focused lifelong learning, that has a concern for social justice at its core" (p289). Clearly, a seniors' perspective on learning, which is currently missing from policy debates, must form the basis for equity in lifelong learning.

Social benefits, relating to seniors' learning, are perhaps less tangible than economic outcomes. However, there are strong arguments that seniors' learning can result in, for example, reduced crime and safer neighbourhoods [43], enhanced social capital, and stronger cross-cultural and intergenerational links [44], and community innovation and adaption to change [23]. Other researchers have studied seniors' involvement in local governance (see [45] and [46]) with the implication that seniors have much to contribute towards a fair and democratic society. This topic is of increasing relevance as seniors gradually gain a proportionally larger voice in democratic decision making processes.

Another example of social benefit is seniors' volunteering, a key example of informal learning through knowledge sharing. This topic has been virtually ignored by Australian governments in the current dialogue on ageing. Seniors' provide, for example, inter-generational childcare, volunteering services, and through various forms of mentoring, pass on their skills, knowledge and experience to others. More research is required to better understand the social and economic value of seniors' volunteering. In particular, there is little understanding of the benefit/cost equation if seniors are encouraged to move from current voluntary roles towards employment.

In terms of individual outcomes, an extensive body of literature has argued that engagement in learning can facilitate positive health and wellbeing outcomes for seniors [26, $38,47-49]$. For example, Tam [50], working from a review of relevant literature, describes how engaging in learning in later life can increase life satisfaction, self-esteem levels and 
instill a sense of independence. Furthermore, Laal [22] suggests lifelong learning can boost focus and concentration, increase confidence and social skills. Such outcomes are well articulated through specific case studies, such as by Aldridge [51] who found that seniors' engagement in learning in care homes increased quality of life and reduced health costs. Benefits to the individual sit on top of the potential economic savings of having good health later in life, thereby placing less pressure on the public health system.

It is apparent that seniors' engagement in learning activity benefits themselves, the community, and the nation. However, while the multiple benefits from seniors' learning are evident, as Tam [20] states “... few studies have shed light on what older people themselves have to say about what they want and need to learn" (p291). This key knowledge gap constrains equitable and informed policy development and operational responses. An evidence base which responds to the three questions listed at the start of this paper is required.

Identification of a need to acknowledge and describe seniors' diversity as a key starting point for research leads our discussion. For example, in discussing the Economic Potential of Senior Australians, the Department of Treasury and Finance [6] identify seniors' diversity in terms of “... cultural and linguistic backgrounds, and different life experiences, lifestyles and aspirations ..." (p1). They continue on to identify the need for longer-term policies which take seniors' diversity into account. Taking the view that 'one size fits all seniors' does not address demographic characteristics, such as generational age cohorts, gender, education levels, cultural background, life experiences and economic status which impact seniors' social and economic development.

\section{ACKNOWLEDGING DIVERSITY WITHIN AN AGE- ING POPULATION: WHAT WE DON'T KNOW}

Globally by 2050 , seniors will constitute $22 \%$ of the world's population, or around two billion people [24]. Obviously, there is great diversity among these 'seniors'. Something more than simplistic or populist policy responses to diversity within ageing and learning is required if we are to achieve the potential health, social and economic outcomes. As Lui et. al. [28] argued, after a comprehensive review of ageing frameworks, “... older people's lives and experiences should be used as a starting point to identify [their] desirable community services and support" (p119).

A recent large scale study across ten European countries found that older people are “... able to recognise and reflect on their learning experiences and to articulate direct benefits as well as the wider benefits and longer-term effects of their learning" (p9) [38]. Arguably, without input from older people any policy making process relating to an ageing population will result in ill-informed or inappropriate responses. Enhanced understanding of the experiences of older Australians is argued as crucial to the design and implementation of appropriate learning policies and strategies to support a productive, healthy and active ageing population [32].

As a starting point towards filling this knowledge gap, we propose a set of factors that are most likely to impact seniors' learning. These factors are based primarily on
Schuller and Watson [3] and our extensive literature review. These impact factors have not been empirically tested but provide a foundation for preliminary discussions and a context for further dialogue.

\section{DIVERSITY ACROSS DIFFERENT STAGES OF A SENIORS' LIFESPAN}

An Australian born in 2012 can expect to live 94 years for females and 92 years for males [16]. As such, seniors can be seen as comprising multiple generations, bought up in vastly different eras, with different life experiences, and as a result having different learning needs. It will become increasingly common for someone to 'be a senior' for $40+$ years, or nearly half a lifetime. However, the ageing literature and policy statements have yet to agree on when a person becomes a 'senior'. Rather than debate this question, in the context of this paper ageing is viewed as a process, and we have adopted a segmented approach to enable appropriate policy responses to be directed to learning needs at different stages of ageing (adapted from [3]; see also [9]). In our approach, seniors are grouped into three cohorts: Emerging seniors (45-60 age cohort); Traditional retirees (61-80 age cohort); and Elders (81+ age cohort).

Diversity across these three age cohorts is also viewed as a lead variable when considering ageing and learning, and specific policy and operational responses are required to cater to each age cohort. In addition, a preliminary set of secondary and perhaps less visible factors including cultural background, marital status, appropriate learning environments, literacies, gender, mobility, health, geographic location, and socio-economic status that potentially impact on seniors' learning must be considered (Fig. 3).

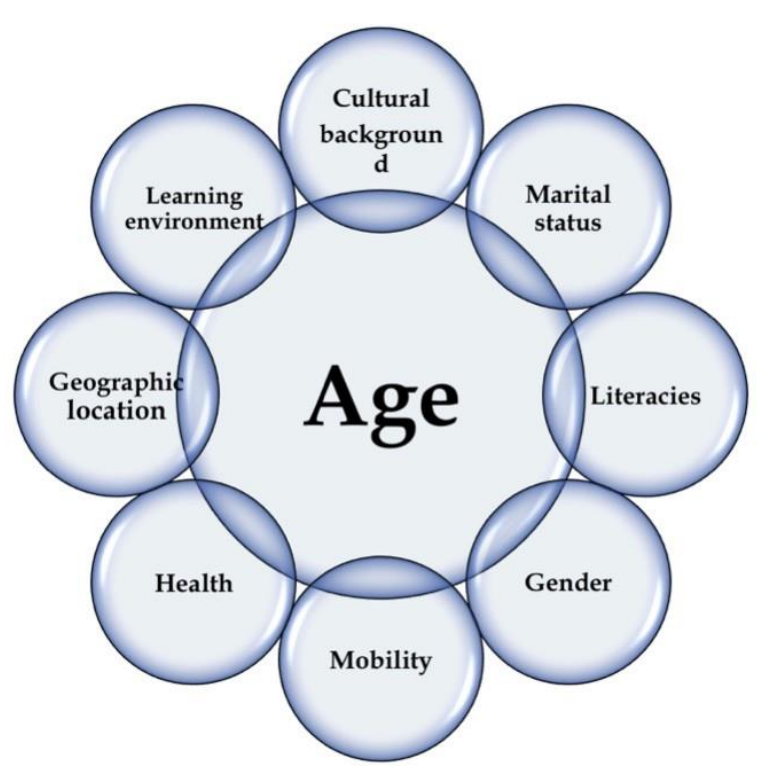

Fig. (3). Interrelated factors impacting on seniors' learning.

Enhanced understanding of how these interrelated and overlapping factors relate to seniors' learning opportunities, preferences, needs and constraints, across each of the three age cohorts, may provide a context to inform ageing and learning policy development and operational initiatives in 
Australia. A summary of key characteristics within each of these impact factors is shown in Table $\mathbf{1}$.

Table 1. Key characteristics of impact factors.

\begin{tabular}{|c|c|}
\hline Impact factor & Key characteristics \\
\hline $\begin{array}{l}\text { Cultural back- } \\
\text { ground }\end{array}$ & $\begin{array}{l}\text { Recognition of the specific needs of seniors from } \\
\text { culturally and linguistically diverse communities, and } \\
\text { Indigenous communities, who “... typically suffer } \\
\text { from higher levels of socio-economic disadvantage } \\
\ldots \text { is crucial to the success of any age-related poli- } \\
\text { cies" [40]. }\end{array}$ \\
\hline $\begin{array}{l}\text { Learning envi- } \\
\text { ronments }\end{array}$ & $\begin{array}{l}\text { While most policy attention is directed to formal } \\
\text { learning environments, little attention has been paid } \\
\text { to important alternative learning needs (social, health, } \\
\text { leisure, etc). Currently, we have little understanding } \\
\text { of the community based learning context for seniors. }\end{array}$ \\
\hline Literacies & $\begin{array}{l}\text { There are a range of literacies, including digital, } \\
\text { English language, information, that are required as } \\
\text { foundations for accessing knowledge and information }\end{array}$ \\
\hline Gender & $\begin{array}{l}\text { Females are more likely to be involved with learning } \\
\text { activities in later life. }\end{array}$ \\
\hline Mobility & $\begin{array}{l}\text { Mobility refers to a range of constraints including } \\
\text { physical mobility and transport options [52]. }\end{array}$ \\
\hline Health & $\begin{array}{l}\text { Health refers to both cognitive and physical limita- } \\
\text { tions to learning. }\end{array}$ \\
\hline $\begin{array}{c}\text { Geographic } \\
\text { location }\end{array}$ & $\begin{array}{l}\text { Locational disadvantage for seniors living in re- } \\
\text { gional/urban/remote communities[41]. }\end{array}$ \\
\hline $\begin{array}{l}\text { Socio- } \\
\text { economic } \\
\text { status }\end{array}$ & $\begin{array}{l}\text { Limited/bad experience with learning environments, } \\
\text { lacking aspiration, lacking relevant information re- } \\
\text { garding pathways for learning, lack of finan- } \\
\text { cial/family support. }\end{array}$ \\
\hline
\end{tabular}

\section{CONCLUSION}

As the United Nations [24] suggest "A society for all ages encompasses the goal of providing older persons with the opportunity to continue contributing to society" [2:Part 2, para. 19]. Responding to this goal requires evidence based policy that understands and incorporates what knowledge and skills seniors require to contribute to society, and how those knowledge and skills might be acquired. Despite a broad dialogue in Australia, relating to the ageing population, and general acknowledgment that lifelong learning supports diverse health, social and economic outcomes, few studies have explored older people's perspectives on what, how or why they want to learn $[20,53]$. The interface between seniors and learning remains an understudied area of research [54].

Australia needs to focus attention on the broad concepts of lifelong learning at government policy and operational levels. Provision of appropriate learning opportunities that support Australian seniors to assuage risk and manage their lives in increasingly complex community settings, will provide crucial support in dealing with the challenges of an ageing population in a positive and equitable manner [18]. By the time an individual is classified as a senior, they will have already spent 40 or more years working, interacting and learning. However, an ageing society should not be seen as a burden. Rather, it should be celebrated and valued. That lifetime of experience can be used to support a just and prosperous society. Providing appropriate learning opportunities to seniors is one clear pathway for achieving that outcome.

\section{CONFLICT OF INTEREST}

No known conflicts of interest.

\section{ACKNOWLEDGEMENTS}

None declared.

\section{REFERENCES}

[1] Adult learning Australia, The ageing population: New opportunities for adult and community education 2013. [Cited: 28 November 2015]. Available from: https://ala.asn.au/wpcontent/uploads/2011/02/The-ageing-population-report-FINALWEB.pdf

[2] Commonwealth of Australia. Australia to 2050: Future challenges (intergenerational report 2010) Australian government, Canberra 2010. [Cited: $28^{\text {th }}$ November 215]. Available from: http://archive.treasury.gov.au/igr/igr2010/Overview/pdf/IGR_2010 _Overview.pdf

[3] Schuller T, Watson D. Learning through life: Inquiry into the future for lifelong learning. Leicester: National Institute of Adult Continuing Education 2009.

[4] Cortright J. National talent dividend network 2011. [Cited: 30th November 2015]. Available from: http://www.ceosforcities.org/work/talentdividendtour

[5]Productivity commission, an ageing Australia: Preparing for the future 2013. [Cited: 29 November 2015] Available from: http://www.pc.gov.au/_data/assets/pdf_file/0005/129749/ageingaustralia.pdf

[6] Department of treasury and finance, realising the economic potential of senior Australians: Turning grey into gold report. The economic potential of senior Australians advisory pane1 2011.

[7] European Commission. Making a European area of lifelong learning a reality 2001. [Cited: 28 ${ }^{\text {th }}$ November 2015] Available from: www.bolognaberlin2003.de/pdf/MitteilungEng.pdf

[8] Cuthill M, Jansen D. Fostering social development and economic prosperity through lifelong learning: First steps in one Australia community. Int J Urban Sustainable Development 2012; 4(1): 6375.

[9] National seniors productive ageing centre, staying connected: Social engagement and wellbeing among mature age Australians 2013. [cited: $30^{\text {th }}$ November 2015] Available from: http://www.productiveageing.com.au/userfiles/file/Final\%20PDF\% 20Low\%20Res\%20Staying\%20Connected.pdf

[10] Tikkanen T, Nyhan B. Promoting lifelong learning for older workers: An international review Cedefop Reference series 65, 2006. [Cited: $30^{\text {th }} \quad$ November 2015] Available from: http://www.cedefop.europa.eu/EN/Files/3045_en.pdf

[11] Duncan W, Whitelock D. (Eds.) The vision splendid: the first publication of Dr. W. G. K. Duncan's report on adult education in Australia, 1944. University of Adelaide, Department of Adult Education, Adelaide 1973.

[12] Commonwealth of Australia, Beyond Cinderella: Towards a learning society. Parliament house, Canberra. 1991. [Cited : 30 November 2015] Available from: http://www.aph.gov.au/Parliamentary_Business/Committees/Senate/ Education_Employment_and_Workplace_Relations/Completed_inqu iries/1996-99/beyond/report/index

[13] Commonwealth of Australia, Come in Cinderella: The emergence of adult and community education. Parliament House, Canberra 1997 
[14] O'Brien S. Educational affinities of old age and youth. Int J Lifelong Learning 1992; 11(2): 125-38.

[15] Davey J. Active ageing and education in mid and later life ageing and society 2002;22(1): 5-113.

[16] Thompson S, Griffin J, Bowman K. The ageing population: New opportunities for adult and community education Adult Learning Australia 2013. Available from: https://ala.asn.au/wpcontent/uploads/2011/02/The-ageing-population-report-FINALWEB.pdf

[17] Kearns P. Achieving Australia as an inclusive learning society: A report on the future directions for lifelong learning in Australia Canberra: Adult Learning Australia 2005. [Cited: $25^{\text {th }}$ November 2015] Available from: https://ala.asn.au/public/docs/report/Kearns_summary_oct05.pdf

[18] Steinberg M, Kearns P, Reghenzani D, Peel M. Harnessing the new demographic: Adult and community learning in older populations. An Australian focus with general implications 2007. [Cited: $25^{\text {th }}$ November 2015] Available from: http://pie.pascalobservatory.org/pascalnow/pascalactivities/news/harnessing-new-demographic-adult-andcommunity-learning-older-popul

[19] Centano V. Lifelong learning: A policy concept with a long past and a short history. Int J Lifelong Education 2011; 30(2): 133-50.

[20] Tam M. Active ageing, active learning: Policy and provision in Hong Kong studies in continuing education 2011; 33(3): 289-99.

[21] Laal M, Salamti P. Lifelong learning; Why do we need it? Procedia Soc Behav Sci 2012; 3: 399-403

[22] Tissot P. Terminology of vocational training policy: A multilingual glossary for an enlarged Europe Cedefop (Ed.), Office for the official publications of the European Communities 2004. Available from: http://www.refernet.pl/zasoby/download/glosariusz.pdf

[23]Ainsworth H, Eaton S. Formal, non-formal and informal learning in the sciences. Calgary (Canada): Onate Press 2010

[24] United Nations World population ageing 2009. [Cited: $25^{\text {th }}$ November 2015] Available from: http://www.un.org/esa/population/publications/WPA2009/WPA200 9_WorkingPaper.pdf

[25] Organisation for economic cooperation and development, lifelong learning for all Paris: OECD 1996.

[26] World Health Organisation, 2002 Active Ageing: A policy framework 2010. Available from: http://whqlibdoc.who.int/hq/2002/who_nmh_nph_02.8.pdf

[27] Everingham J, Lui C, Bartlett H, Warburton J, Cuthill M. 'Rhetoric to action: A study of stakeholder perceptions of ageing well in two local communities'. J Gerontol Soc Work 2010; 53: 760-75.

[28] Lui C, Everingham J, Warburton J, Cuthill M, Bartlett H. What makes a community age-friendly: A review of international literature. Australas J Ageing 2009; 28(3): 116-21.

[29] Adams K, Leibbrandt S, Moon H. A critical review of the literature on social and leisure activity and wellbeing in later life. Ageing Soc 2011;31(4): 683-712.

[30] Maranti R, Yu P. Persistence of social exclusion among older people in Australia: What are the protecting factors? NATSEM Working Paper 11/11. 2011, Available from: http://www.natsem.canberra.edu.au/storage/WP11\%20Final.pdf

[31] Jackson S. Lifelong learning and social justice: Communities, work and identities in a Globalised world NIACE: England and Wales 2011

[32] Withnall A. Improving learning in later life London; Routledge 2010

[33] Organisation for economic cooperation and development. Cities and regions in the new learning economy. Paris: OECD 2001. Available from: http://www.oecd.org/document/6/0,3343,fr_2649_35961291_2010 118_1_1_1_1,00.html

[34] Organisation for economic cooperation and development, Improving health and social cohesion through education. Centre for educational research and innovation, OECD 2010. Available from: http://www.oecd.org/document/36/0,3746,en_2649_35845581_461 30468_1_1_1_1,00.html
[35] United nations political declaration and madrid international plan of action on ageing 2002. Available from: http://cfam.org/docLib/20080625_Madrid_Ageing_Conference.pdf

[36] Watson L. Lifelong learning in Australia Canberra: Department of education, science and training, commonwealth of Australia 2003. Available http://www.dest.gov.au/sectors/higher_education/publications_reso urces/other_publications/lifelong_learning_in_australia.htm\#

[37] Schuller T, Preston J, Hammond C, Brassett-Grundy A, Bynner J. The benefits of learning: The impact of education on health, family life, and social capital. Routledge Falmer, London and New York 2004.

[38] BeLL. Benefits of lifelong learning. German institute for adult education leibniz centre for lifelong learning 2014. [Cited: $25^{\text {th }}$ November 2015] Available from: http://www.bellproject.eu/cms/wp-content/uploads/2014/06/Final-Report1.pdf

[39] Healy J. The benefits of an ageing population. Discussion paper No. 63, The Australia Institute, Australian National University Canberra. 2004

[40] Per Capita Australia. Blueprint for an ageing Australia 2014. [Cited: 25 $5^{\text {th }}$ November 2015] Available from http://percapita.org.au/wpcontent/uploads/2014/11/BlueprintForAnAgeingAustralia.pdf

[41] Buys L, Burton L, Cuthill M, Hogan A, Wilson B, Baker D. Establishing and maintaining social connectivity: An understanding of the lived experiences of older adults residing in regional and rural communities. Aust J Rural Health 2015; 23(5): 291-4.

[42] Australian human rights commission, Fact or fiction: Stereotypes of older Australians research report 2013. [Cited: $29^{\text {th }}$ November 2015] Available from: https://www.humanrights.gov.au/sites/default/files/document/publi cation/Fact\%20or\%20Fiction_2013_WebVersion_FINAL_0.pdf

[43] The Scottish Executive. Life through learning; Learning through life. The Lifelong Learning Strategy for Scotland 2003. [Cited: $29^{\text {th }}$ November 2015] Available from: http://www.gov.scot/Resource/Doc/47032/0028819.pdf

[44] Nordstrom N, Merz J. Learning later, living greater: The secret for making the most of your after-50 years. Colorado: Sentient Boulder Co. Publishing 2006.

[45] Petriwskyj A, Warburton J, Everingham J, Cuthill M. Diversity and inclusion in local governance: An Australian study of seniors' participation. J Aging Stud 2012; 26(2): 182-91

[46] Petriwskyj A, Everingham J, Warburton J, Cuthill M. Seniors' motivations for participation in local governance: Evidence from an Australian study. Local Government Studies 2014; 40(2): 240-63.

[47] Feinstein L, Sabates R, Anderson T, Sorhaaindo A, Hammond C. 'What are the effects of education on health?' Measuring the effects of education on health and civic engagement: Proceedings of the Copenhagen symposium 2006. [Cited: $29^{\text {th }}$ November 2015] Available from: https://www1.oecd.org/edu/innovationeducation/37425753.pdf

[48] Hammond C, Feinstein L. Are those who flourished at school healthier adults? What role for adult education? London: Centre for research into the wider benefits of learning 2006.

[49] Australian pensioners insurance agency. Understanding over 50s: An APIA research report 2007. [Cited: $29^{\text {th }}$ November 2015] Available

from:https://www.humanrights.gov.au/sites/default/files/document/ publica-

tion/Fact\%20or\%20Fiction_2013_WebVersion_FINAL_0.pdf

[50] Tam M. Active ageing active learning: Elder learning in Hong Kong. In: Boulton-Lewis, G and Tam M, Eds. Active ageing active learning, Issues and Challenges Education in the Asia Pacific Region: Issues, concerns and prospects. Springer Science+Business Media B.V 2012; pp. 163-74.

[51] Aldridge F. Enhancing informal adult learning for older people in care settings: Interim report and consultation document. Leicester: NIACE 2009. [Cited: 29 ${ }^{\text {th }}$ November 2015] Available from: http://adass.org.uk/AdassMedia/stories/Enhancing\%20Information $\% 20$ Adult $\% 20$ learning $\% 20$ for $\% 20$ Older $\% 20$ People $\% 20$ in $\% 20$ care \%20settings.pdf 
[52] Zeitler E, Buys L, Aird R, Miller E. Mobility and active ageing in suburban environments: Findings from in-depth interviews and person-based GPS tracking. Curr Gerontol Geriatr Res 2012: 110.
[53] Schofield D, Callander E, Kelly S, Shrestha R. Working beyond 65 - What's realistic? The influence of health on longer working lives. Melbourne: National Seniors Productive Ageing Centre 2014

[54] Findsen B, Formosa M. Lifelong Learning in Later Life. Rotterdam/Boston/Taipei: Sense Publishers 2011. 